\title{
Expression, purification and DNA-binding activities of two putative ModE proteins of Herbaspirillum seropedicae (Burkholderiales, Oxalobacteraceae)
}

\author{
André L.F. Souza, Leda S. Chubatsu, Emanuel M. Souza, Fábio O. Pedrosa, Rose A. Monteiro, \\ Fabiane G.M. Rego and Liu U. Rigo \\ Departamento de Bioquímica e Biologia Molecular, Universidade Federal do Paraná, Curitiba, PR, Brazil.
}

\begin{abstract}
In prokaryotes molybdenum is taken up by a high-affinity $A B C$-type transporter system encoded by the modABC genes. The endophyte $\beta$-Proteobacterium Herbaspirillum seropedicae has two modABC gene clusters and two genes encoding putative Mo-dependent regulator proteins (ModE1 and ModE2). Analysis of the amino acid sequence of the ModE1 protein of $H$. seropedicae revealed the presence of an $\mathrm{N}$-terminal domain containing a DNA-binding helix-turn-helix motif $(\mathrm{HTH})$ and a C-terminal domain with a molybdate-binding motif. The second putative regulator protein, ModE2, contains only the helix-turn-helix motif, similar to that observed in some sequenced genomes. We cloned the modE1 (810 bp) and modE2 (372 bp) genes and expressed them in Escherichia coli as His-tagged fusion proteins, which we subsequently purified. The over-expressed recombinant His-ModE1 was insoluble and was purified after solubilization with urea and then on-column refolded during affinity chromatography. The His-ModE2 was expressed as a soluble protein and purified by affinity chromatography. These purified proteins were analyzed by DNA band-shift assays using the modA2 promoter region as probe. Our results indicate that His-ModE1 and His-ModE2 are able to bind to the modA2 promoter region, suggesting that both proteins may play a role in the regulation of molybdenum uptake and metabolism in $H$. seropedicae.
\end{abstract}

Key words: Herbaspirillum seropedicae, ModE1 protein, ModE2 protein.

Received: August 17, 2007; Accepted: November 8, 2007.

\section{Introduction}

Molybdenum (Mo) is an essential trace element, which is part of the catalytic site of important enzymes such as nitrate reductase, nitrogenase and xanthine oxidase (Hille, 1996). Molybdenum is predominantly found in nature as the $\mathrm{MoO}_{4}{ }^{2-}$ oxyanion, and is the only second-row transition metal required by most living organisms. Because the concentration of molybdenum in the environment is low, the majority of prokaryotes have high-affinity molybdate ABC-type uptake systems coded by the $\bmod A B C$ genes which must be able to distinguish between molybdate and chemically similar oxyanions such as sulfate, phosphate and vanadate (Corcuera et al., 1993; Self et al., 2001). In Escherichia coli the expression of the mod operon is regulated by the ModE protein in response to the intracellular molybdenum concentration. The ModE-molybdate complex binds with high affinity to the $\bmod A B C$ promoter region and represses its transcription (Anderson et al., 1997; McNicholas et al., 1998b) and can also enhance the transcription of some operons coding for molybdoenzymes and

Send correspondence to Liu Un Rigo. Departamento de Bioquímica e Biologia Molecular, Universidade Federal do Paraná, 81531-990 Curitiba, PR, Brazil. E-mail: lurigo@ufpr.br. proteins of the molybdopterin biosynthesis pathway (Anderson et al., 2000; Self et al., 2001).

It is known that E. coli ModE is a homodimer with a helix-turn-helix (HTH) DNA-binding motif at the N-terminal domain and a molybdate-binding site at the $\mathrm{C}$-terminal DiMop domain, which is made up of two sub-domains in tandem that bind two molybdate ions per dimer at the domain interfaces (Hall et al., 1999; Schüttelkopf et al., 2003). Structural data have revealed that E. coli ModE discriminates between oxyanions based on size and charge, with the C-terminal domain undergoing a conformational change induced by the ligand which results in an alteration of the surface of the dimer and is a molecular switch regulating the recruitment of the partner proteins necessary for the positive regulation of transcription (Gourley et al., 2001). The structures of E. coli ModE in its liganded on holo-state and unliganded off apo-state have been determined by Schüttelkopf et al. (2003), a major change between the two states being the relative orientation of the two HTH motifs at the N-terminal which suggests that this conformational change enhances the DNA binding activity of the ModE-molybdate complex. 
Several Bacteria and Archaea encode proteins that contain the DNA-binding domain characteristic of ModE, but completely lack a molybdate-binding domain and cannot bind molybdate, although their HTH-containing domains are probably capable of binding DNA (Studholme and Pau, 2003). The microaerobic endophytic diazotroph Herbaspirillum seropedicae (Burkholderiales, Oxalobacteraceae) associates with several Gramineae of economic interest (Baldani et al., 1986; Young, 1992). While E. coli contains only a single copy of molybdenum ABC-type transport system, $H$. seropedicae has two distinct clusters encoded by mod $A B C$-like genes in its genome sequence. In addition $H$. seropedicae has two genes ( $\operatorname{modE1} 1$ and $\operatorname{modE2}$ ) coding for two ModE-like regulator proteins. Sequence analysis has revealed that the $\operatorname{modE1}$ product has a typical ModE domain architecture, with an HTH motif at the N-terminal domain and a DiMop domain with two Mop subdomains at the C-terminal (Schultz et al., 1998 and Letunic et al., 2006), while the modE2 product shows only the HTH motif related to DNA binding. Similar structures have been observed in homologous proteins of other bacteria (Studholme and Pau, 2003).

In this paper we describe how we have over-expressed and purified both ModE1 and ModE2 proteins and analyzed their DNA-binding activity at the $H$. seropedicae $\bmod A 2 B 2 C 2$ promoter region.

\section{Materials and Methods}

\section{Bacterial strains, plasmids and growth conditions}

The $E$. coli strains and plasmids used in this study are given in Table 1. Cells were grown in Luria broth (LB) or LB-agar and, when required, kanamycin was added at a concentration of $50 \mu \mathrm{g} \mathrm{mL}^{-1}$. All chemicals were at least analytical grade and were purchased from Merck Biosciences (Germany) or Sigma-Aldrich (Germany) unless otherwise stated. Mo-free solutions were prepared using activated charcoal-treated water as described by Schneider et al., (1991).

\section{Cloning of modE1 and modE2}

All manipulations were performed as described in Sambrook et al. (1989). We used H. seropedicae genomic DNA as the template for the polymerase chain reaction (PCR) amplification of modE1 with the oligonucleotide NdeI-modE1R (5'CATCGGCAAGCATATGAGTACC3'), BamHI-modE1F (5'GGTGTCAGGATCCCAGAATG3') and modE2 with the oligonucleotide NdeI-modE2R (5'GTACAATCACGCATATGAATG3'), BamHI-modE2 (5'GCAGGCGGATCCGGTATTTG3'), the primers containing NdeI or Bam HI restriction sites (underlined) for further manipulations. The PCR products containing modE1 (874 bp) and modE2 (415 bp) were directly cloned into the $\mathrm{pCR}^{\circledR} 2.1$ TOPO plasmid vector (Invitrogen, USA) giving the plasmids pCR2.1modE1 and pCR2.1modE2, respectively. The plasmids pCR2.1modE1 and pCR2.1modE2 were then digested with NdeI and BamHI (MBI Fermentas, Germany) and the fragments containing modE1 and modE2 were purified using QIAquick gel extraction kit (Qiagen) and inserted into the expression vector pET-28a $(+)$, resulting in the pET28amodE1 and pET28amodE2 plasmids. The inserts of these two plasmids were sequenced using DYEnamic ET Terminator Cycle Sequencing Kit (GE HealthCare) in an ABI PRISM 377 DNA Sequencer to confirm that no mutation was introduced during the amplification procedure. The pET28amodE1 plasmid expressed ModE1 and the pET28amodE2 plasmid expressed ModE2 as the polyhistidine-tag (His-tag) fusion proteins HisModE1 and His-ModE2. These plasmids were introduced into $E$. coli strain BL21(DE3) by electrotransformation for protein expression and purification.

\section{Over-expression and purification of $H$. seropedicae His-ModE1 and His-ModE2}

Cells carrying the pET28amodE1 or pET28amodE2 plasmids were grown aerobically in $250 \mathrm{~mL}$ of LB medium at $37^{\circ} \mathrm{C}$ to an optical density of approximately 0.3 measured at $\lambda=600 \mathrm{~nm}$ in a photospectrometer and $0.5 \mathrm{mM}$ of

Table 1 - Bacterial strains and plasmids.

\begin{tabular}{|c|c|c|}
\hline Strain/plasmid & Characteristics* & Source \\
\hline E. coli BL21(DE3) & Host for expression of His-ModE1 and His-ModE2 proteins & Novagen, Darmstadt, Germany \\
\hline H. seropedicae SMR1 & Wild type, $\mathrm{Nif}^{+}, \mathrm{Sm}^{\mathrm{R}}$ & Souza et al., $2000^{\dagger}$ \\
\hline HS05-EG-048-B06 & $1.5 \mathrm{kbp}$ insert of $H$. seropedicae genome in $\mathrm{pUC} 18 \mathrm{R}$ cloning vector, $\mathrm{Ap}^{\mathrm{R}}$ & Genopar Consortium \\
\hline pET-28a $(+)$ & High-copy His-tag expression vector; $\mathrm{Km}^{\mathrm{R}}$ & Novagen, Darmstadt, Germany \\
\hline $\mathrm{pCR}^{\circledR} 2.1 \mathrm{TOPO}$ & TA cloning vector, lac $Z \alpha$ fragment, $\mathrm{Km}^{\mathrm{R}}, \mathrm{Ap}^{\mathrm{R}}$ & Invitrogen, Carlsbad, USA \\
\hline pCR2.1modE1 & $\mathrm{pCR}^{\circledR} 2.1$ derivative carrying $\bmod 1 \mathrm{PCR}$ product & This study \\
\hline pCR2.1modE2 & $\mathrm{pCR}^{\circledR} 2.1$ derivative carrying modE2 $\mathrm{PCR}$ product & This study \\
\hline pET28amodE1 & pET-28a(+) derivative carrying $N$ deI-Bam $\mathrm{HI}$ modE1 gene from $H$. seropedicae & This study \\
\hline pET28amodE2 & pET-28a(+) derivative carrying $N d e \mathrm{I}-B a m \mathrm{HI}$ modE2 gene from $H$. seropedicae & This study \\
\hline
\end{tabular}

*Km, kanamycin; Ap, ampicillin. ${ }^{\dagger}$ Microbiology 146:1407-1418. 
isopropyl- $\beta$-D-thiogalactopyranoside (IPTG) was added to induce expression of the recombinant proteins. After $3 \mathrm{~h}$ incubation at $37^{\circ} \mathrm{C}$ the cells were harvested and stored frozen at $-80^{\circ} \mathrm{C}$ until extraction and purification of the His-ModE1 and His-ModE2 proteins. To purify His-ModE1 we re-suspended induced cells in $20 \mathrm{~mL}$ of lysis buffer $(0.05 \mathrm{M}$ Tris- $\mathrm{HCl} \mathrm{pH}$ 8, $0.5 \mathrm{M} \mathrm{NaCl}, 0.01 \mathrm{M}$ EDTA, $1 \mathrm{mM}$ phenylmethyl-sulfonylfluoride (PMSF), $200 \mu \mathrm{g} \mathrm{mL}^{-1}$ lysozyme and $10 \%(\mathrm{w} / \mathrm{v})$ glycerol), kept on ice for $30 \mathrm{~min}$ and disrupted by sonication using an Ultrasonic processor XL (Heat Systems) at $40 \%$ maximum intensity for five thirty-second bursts. The crude extract was centrifuged at $12,000 \mathrm{~g}$ for $15 \mathrm{~min}$ at $4{ }^{\circ} \mathrm{C}$ and the supernatant (S1) stored and the pellet resuspended by gentle agitation for one hour on ice in $20 \mathrm{~mL}$ of wash buffer (2 M urea, $0.05 \mathrm{M}$ Tris- $\mathrm{HCl} \mathrm{pH} 8$, $0.5 \mathrm{M} \mathrm{NaCl}$ and $0.5 \%(\mathrm{w} / \mathrm{v})$ Triton X-100) and then re-sonicated as described above, this process being repeated twice two produce two further supernatant fractions ( $\mathrm{S} 2$ and $\mathrm{S} 3$ ). The washed inclusion bodies were resuspended in $20 \mathrm{~mL}$ of solubilization buffer $(8 \mathrm{M}$ urea, $0.5 \mathrm{M} \mathrm{NaCl}$ and $0.05 \mathrm{M}$ Tris- $\mathrm{HCl} \mathrm{pH} \mathrm{8)} \mathrm{and} \mathrm{centrifuged} \mathrm{as} \mathrm{described} \mathrm{above} \mathrm{to} \mathrm{re-}$ move remaining aggregates which could act as nuclei for aggregation during refolding. The supernatant (S4) containing the solubilized His-ModE1 was loaded onto a $5 \mathrm{~mL}$ HiTrap Chelating HP (GE Healthcare) charged with $\mathrm{Ni}^{2+}$ and equilibrated with solubilization buffer, 10 volumes of which was used to the column. For His-ModE1 refolding, the column was washed with 20 volumes of buffer A $(0.05 \mathrm{M}$ Tris- $\mathrm{HCl} \mathrm{pH} 8$ and $0.5 \mathrm{M} \mathrm{NaCl})$ with an $8 \mathrm{M}$ to $0 \mathrm{M}$ decreasing linear gradient of urea at a flow rate of $2 \mathrm{~mL}$ $\mathrm{min}^{-1}$ and then with 5 volumes of the same buffer before eluting the on-column refolded His-ModE1 protein using 10 volumes of buffer A with a linear gradient of imidazole increasing to $1 \mathrm{M}$. The $0.28 \mathrm{M}$ to $0.4 \mathrm{M}$ imidazole fractions containing His-ModE1 were pooled and dialyzed against buffer A containing $50 \%(\mathrm{w} / \mathrm{v})$ glycerol for $20 \mathrm{~h}$ at $4{ }^{\circ} \mathrm{C}$ and the purified protein stored at $-80^{\circ} \mathrm{C}$ in $100 \mu \mathrm{L}$ aliquots. To purify His-ModE2 we resuspended the induced cells in $20 \mathrm{~mL}$ of lysis buffer $(0.05 \mathrm{M}$ Tris- $\mathrm{HCl} \mathrm{pH} 8.0,0.5 \mathrm{M} \mathrm{NaCl}$ and $10 \%(\mathrm{w} / \mathrm{v})$ glycerol) and disrupted by sonication and centrifuged as described above. After centrifugation the supernatant, containing soluble His-ModE2, was loaded onto a HiTrap Chelating $\mathrm{Ni}^{2+}$ affinity column (GE Healthcare) equilibrated with buffer $\mathrm{A}$ and 10 volumes of buffer A with an increasing linear gradient of imidazole up to $1 \mathrm{M}$ was used to elute the His-ModE2 protein at an imidazole concentration of between $0.32 \mathrm{M}$ and $0.36 \mathrm{M}$. The fractions containing the protein were pooled and glycerol added to a final concentration of $50 \%(\mathrm{w} / \mathrm{v})$ and the His-tagged ModE2 stored at $-80^{\circ} \mathrm{C}$.

We analyzed the expressed proteins by sodium dodecyl sulfate-polyacrylamide gel electrophoresis (SDSPAGE) according to the method of Laemmli (1970), the gels being stained with Coomassie brilliant blue R-250. Molecular weight markers (GE Healthcare) were run along with the proteins. Protein quantification was performed as described by Bradford (1976) using bovine serum albumin as standard. The purity of His-ModE1 and His-ModE2 proteins was estimated by densitometric analysis using an UVP (Inc. Upland, CA USA) transilluminator.

\section{DNA band shift assay}

The shotgun library of the $H$. seropedicae genome project provided the HS05-EG-048-B06 plasmid carrying the $\bmod A 2$ promoter region. Following digestion of the plasmid with $B a m \mathrm{HI}$ from the cloning vector and NheI, the $340 \mathrm{bp}$ DNA fragment was extracted from a $0.8 \%(\mathrm{w} / \mathrm{v})$ agarose gel and cleaned using the QIAquick Gel Extraction kit (Qiagen).

For the DNA binding assays we used the Klenow enzyme (New England Biolabs) to label the $340 \mathrm{bp}$ DNA fragment with $10 \mathrm{mCi} \mathrm{mL}^{-1}\left[\alpha^{32} \mathrm{P}\right]$-dCTP according to method of random primer labeling (Sambrook et al., 1989) and cleaned the product with a PCR clean-up kit (Qiagen). The $10 \mu \mathrm{L}$ reaction mixtures contained $5 \mathrm{nM}$ of $\left[{ }^{32} \mathrm{P}\right]$-endlabelled $340 \mathrm{bp}$ DNA and $3 \mu \mathrm{g} \mathrm{mL}^{-1}$ of heterologous herring DNA in binding buffer $(0.05 \mathrm{M} \mathrm{KCl}, 0.01 \mathrm{M}$ Tris- $\mathrm{HCl}$ $\mathrm{pH} 8.0,7 \mathrm{mM} \mathrm{MgCl}_{2}, 1 \mathrm{mM}$ EDTA, $1 \mathrm{mM}$ DTT and $10 \%$ (w/v) glycerol) (McNicholas et al., 1997), the reactions being started by the addition of 100-800 $\mathrm{nM}$ of His-ModE1 or His-ModE2 (Figure 4A) and incubated at room temperature for $10 \mathrm{~min}$. After incubation, reactions were loaded on a $4 \%$ non-denaturing polyacrylamide gel (19:1) in TBE buffer (Sambrook et al., 1989). Electrophoresis was carried out at $60 \mathrm{~V}$ for $2 \mathrm{~h}$ at $4{ }^{\circ} \mathrm{C}$. The gels were dried on a GD-1 slab gel dryer and visualized using a Storm 820 Phosphorimager (GE Healthcare).

\section{Results and Discussion}

The $H$. seropedicae sequences obtained by us are available under the following GenBank accession numbers: Z54207 for nifHDK; AF088132 for nifENXorflorf2; EF666057 for fdxAnifQmodA1B1C1; AY007317 for modE1; M60319 for nifA; and EF666058 for $\bmod E 2 \bmod A 2 B 2 C 2$.

\section{Genetic organization of $H$. seropedicae modABC genes}

Genes coding for a putative ABC-type molybdate transport system (modA1B1C1) were previously found downstream from the nifHDKENXorflorf2fdxAnifQ genes in H. seropedicae (Klassen et al., 1999). A similar organization was observed in the phototrophic purple bacterium Rhodobacter capsulatus (Wang et al., 1993). In $H$. seropedicae, the modA1B1Cl gene cluster probably forms a single operon with the nif genes under the control of the nifH promoter (Machado et al., 1996; Klassen et al., 1999) (Figure 1A). A modE--like gene, named modE1, is also located in the nif region downstream from the nifA gene and 
$24.5 \mathrm{kbp}$ downstream from the modAl gene. Our $H$. seropedicae genome sequencing identified a second related mod cluster, named modA2B2C2, located in a distinct region of the genome, probably forming a single operon with another $\bmod E$-like gene, $\bmod 22$, immediately upstream and transcribed divergently from $\bmod A 2$. The organization of this gene cluster is more closely related to that seen in most other microorganisms, including E. coli, Haemophilus influenzae, Azotobacter vinelandii and $R$. capsulatus (Grunden and Shanmugam, 1997). Two ModE-like proteins have been found in some organisms (Studholme and Pau, 2003) but this organization has not been studied in detail. The DNA of $R$. capsulatus codes for two similar but functionally non-identical Mo-dependent regulators (MopA and MopB proteins), which have overlapping function in the Mo-dependent repression of $\bmod A B C$, anfA (coding for an ABC-type high-affinity Mo transport system), $\operatorname{mor} A B$ and $\bmod C$ (mor $A B C$ genes code for a putative ABC-type transport system of unknown function). However, Wiethaus et al. (2006) reported that the Mo-dependent activation of the mop gene (coding for a putative Mo-binding protein) is performed by MopA protein but not by MopB.

\section{ModE1 protein}

We isolated modEl from the H. seropedicae genome project shotgun genomic library and sequence analysis confirmed that this gene is $810 \mathrm{bp}$ long and has high similarity to $\operatorname{modE}$ from Burkholderia xenovorans

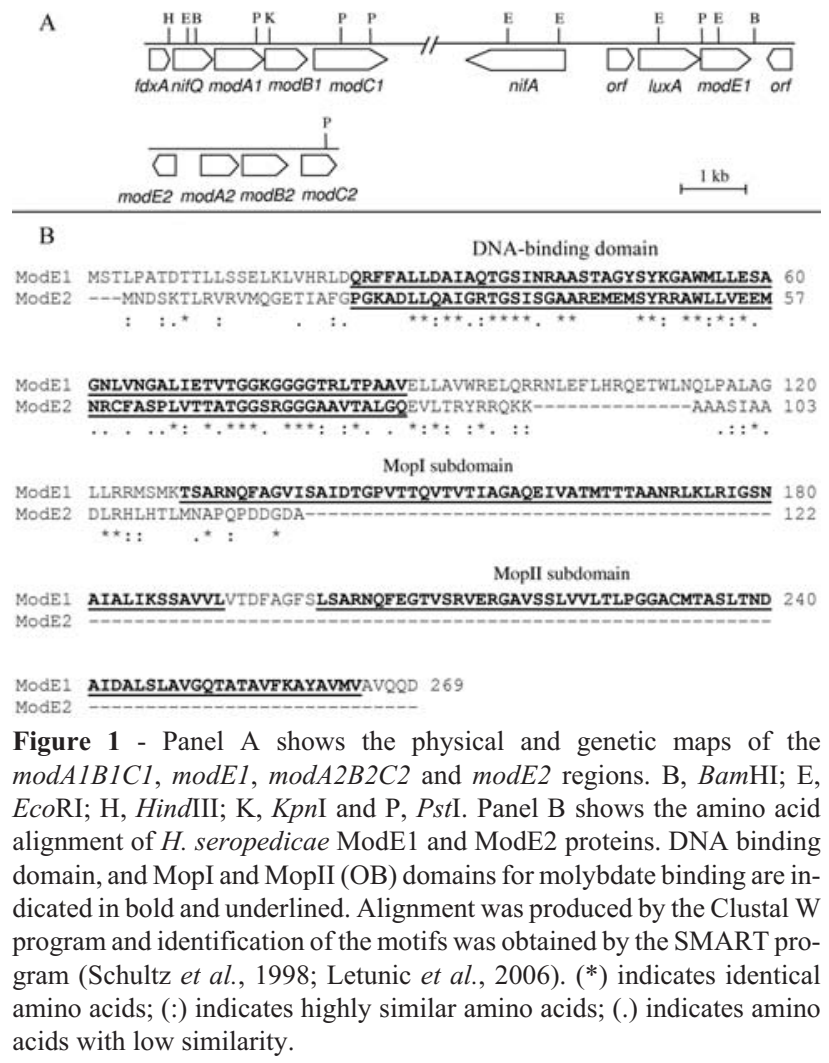

LB400 (GenBank YP_553832; 80\% identity) and Burkholderia vietnamiensis G4 (GenBank YP_001115213; 70\% identity). The protein we deduced from the $\bmod E 1$ produced a protein containing 269 amino acids and a calculated molecular mass of $28 \mathrm{kDa}$. Our in silico analysis revealed an $\mathrm{N}$-terminal domain (residues 28 to 88 ) characteristic of molybdenum binding proteins (Protein families (Pfam) accession number 00126) and which contains a HTH motif probably involved in DNA-binding (McNicholas et al., 1998b; Studholme and Pau, 2003). At the C-terminal region of the ModE1 protein we found two transport-associated OB (DiMop) domains (residues 129 to 192 and 201 to 264) (Pfam 03459) similar to a molybdate-binding domain (MopI and MopII subdomains) (Figure 1B) (Schultz et al., 1998; Letunic et al., 2006). This domain organization of the H. seropedicae ModE1 is similar to the E. coli ModE proteins (McNicholas et al., 1998b; Hall et al., 1999; Schüttelkopf et al., 2003; Studholme and Pau, 2003). To analyze the H. seropedicae ModE1 protein we constructed a plasmid to over-express ModE1 as a fusion to a His-tag sequence. Although several procedures were tested (data not shown), the His-ModE1 protein was found to be in an insoluble form (Figure 2A). Modifications of the induction temperature, use of lactose and modification of the lysis buffer composition and or the salt concentration did not improve the solubility of His-ModE1, but even so the expressed protein represented over $40 \%$ of the total cell protein content as determined by SDS-PAGE densitometry. Due to the difficulty in obtaining soluble $H$. seropedicae His-ModE1 we developed a procedure for solubilization of the inclusion bodies and refolding of the denatured protein. The soluble fraction after cell sonication showed a very faint His-ModE1 band, indicating that the majority of the protein was insoluble (Figure 2A). The use of sonication to lyse the cells in the presence of lysozyme produced a pellet with a minimum contamination of intact cells or cell debris and sheared genomic DNA. The insoluble protein was then solubilized and semi-purified with urea and affinity chromatography, the His-ModE1 protein being eluted with an imidazole gradient in a soluble form with an overall yield of $4 \%$ and a purity of up to $98 \%$ as determined by densitometric analyses of Coomassie-stained SDS-PAGE gels (Figure 2A). The stored frozen imidazole aliquots were shown to be stable for several months and no precipitated His-ModE1 protein was observed. The His-ModE1 protein was tested for DNA-binding using the $H$. seropedicae modA2 promoter region. We also tested the protein refolding procedure using dialysis to decrease the amount of urea, however, protein precipitation was observed (data not shown). Since the mobility of column-bound proteins is restricted, the formation of protein aggregates is less prone to occur when the denaturing agent is decreased. 
A

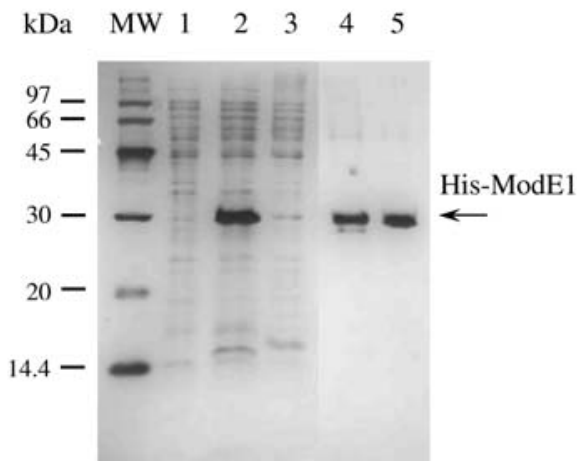

B

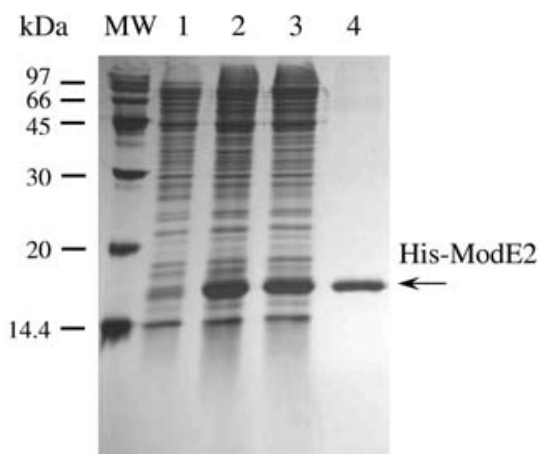

Figure 2 - Electrophoresis (15\% SDS-PAGE) of the over-expression and purification of the H. seropedicae His-ModE1 and His-ModE2 proteins. Panel A shows His-ModE1 lanes: lane 1, total cellular protein (TCP) of non-induced E. coli BL21(DE3) carrying pET28amodE1; lane 2, TCP of $E$. coli BL21(DE3) carrying pET28amodE1 induced by $0.5 \mathrm{mM}$ isopropyl- $\beta$-D-thiogalactoside (IPTG) for $3 \mathrm{~h}$ at $37^{\circ} \mathrm{C}$; lane 3 , soluble fraction of the crude extract (S1); lane 4, sample after solubilization with $8 \mathrm{M}$ urea (S4); and lane 5, purified fraction of His-ModE1. Panel B shows His-ModE2 lanes: lane 1, TCP of non-induced E. coli BL21(DE3) carrying pET28amodE2; lane 2, TCP of E. coli BL21(DE3) carrying pET28amodE2 induced by $0.5 \mathrm{mM}$ IPTG for $3 \mathrm{~h}$ at $37^{\circ} \mathrm{C}$; lane 3 , soluble fraction of the crude extract; and lane 4, purified fraction of His-ModE2. Molecular weight (MW) markers in kDa). Arrows indicate the His-tag proteins. Proteins were stained with Coomassie brilliant blue R-250.

\section{ModE2 protein}

In our study we confirmed that the $H$. seropedicae modE2 is $372 \mathrm{bp}$ long and codes for a protein made up of 122 amino acids and with a predicted size of $13 \mathrm{kDa}$. This protein has a DNA-binding domain made up of 21 to 85 amino acids residues (Pfam 00126) (Schultz et al., 1998; Letunic et al., 2006) which is similar to the N-terminal domain of the molybdenum-binding protein of Methylobacillus flagellatus KT (GenBank YP_546401; 53\% identity), Novosphingobium aromaticivorans DSM 12444 (GenBank YP_497784; 60\% identity), and Methylococcus capsulatus str. Bath (GenBank YP_113805; 51\% identity). However, ModE2 does not show a molybdate-binding domain, a domain that is also missing in similar proteins of other organisms (Studholme and Pau, 2003). When we compared ModE1 and ModE2 we found that these proteins have low sequence identity (14\%) and similarity $(16 \%)$ as shown in Figure 1B, with the highest identity shared in the HTH domain. In contrast to His-ModE1, the His-ModE2 protein over-expressed in E. coli BL21(DE3) carrying the plasmid pET28amodE2 was mostly in a soluble form (Figure 2B). This solubility difference may be because of the lower content of hydrophobic amino acids in His-ModE2. We purified His-ModE2 from the soluble fraction of the crude extract using standard $\mathrm{Ni}^{+2}$ affinity chromatography, with $50 \%(\mathrm{v} / \mathrm{v})$ glycerol being added to the pooled affinity chromatography protein fractions because precipitation occurred when high concentrations of His-ModE2 were dialyzed. The overall His-ModE2 protein yield was $10.4 \%$ and its purity was $98 \%$ as determined by densitometric analyses of Coomassie-stained SDS-PAGE gels (Figure 2B).

\section{DNA-binding activity of His-ModE1 and His-ModE2}

The ModE proteins regulate the transcription of $\bmod A B C$ genes in response to molybdenum availability in
E. coli and this regulation is based on the binding of the ModE-molybdate complex to a conserved binding sequence in the promoter region of the target genes (Grunden et al., 1996; Anderson et al., 1997; McNicholas et al., 1997; Grunden et al., 1999; Self et al., 2001). Furthermore, ModE also seems to regulate the expression of other genes involved with molybdenum (Anderson et al., 2000; McNicholas et al., 1998a; Tao et al., 2005).

Sequence analysis of the $H$. seropedicae modE2$\bmod A 2$ intergenic region revealed that it contains the TATAT-N - $_{7}$ TATAT motif, very similar to the ModEprotected regions of the $\operatorname{modA}$ operator/promoter DNA after DNase I footprinting in E. coli (Anderson et al., 1997; McNicholas et al., 1997; Grunden et al., 1999), indicating that this sequence is the target for ModE1 and/or ModE2 proteins. In a variety of organisms the TATAT- $\mathrm{N}_{7}$-TATAT motif sequence is similar to the operator/promoter DNA sequence of operons known to be under molybdate control and repressed by ModE-molybdate or its homologs (Gourley et al., 2001; Self et al., 2001). The probable $H$. seropedicae ModE binding site overlaps the -10 region of the putative $\sigma^{70}$-dependent $\bmod A 2$ promoter, as also reported in the E. coli modE-modABC regulating region (Anderson et al., 1997; Grunden et al., 1999), further suggesting that these genes are regulated by a ModE-like protein (Figure 3). To further investigate this we used a $340 \mathrm{bp} \mathrm{H}$. seropedicae modA2 promoter region fragment and the DNA band-shift assay to test the binding of HisModE1 and His-ModE2 proteins to target DNA (Figure 4). Both purified His-ModE1 and His-ModE2 proteins bound to the $\bmod A 2$ promoter region in the presence of excess ( $3 \mu \mathrm{g} \cdot \mathrm{mL}^{-1}$ ) unlabelled heterologous herring DNA, as revealed by a decrease in the migration rate of the $\left[{ }^{32} \mathrm{P}\right]$-labelled $\bmod A 2$ promoter DNA fragment (Figure 4A). The ratio of protein-bound DNA was dependent on the protein 
concentration (Figure 4A) and $600 \mathrm{nM}$ of purified HisModE1 and His-ModE2 bound to $100 \%$ of the DNA in the system (Figures 4B and C). Also, with the increasing concentration of unlabelled $\bmod A 2$ promoter region, the binding of the labeled DNA was diluted out, indicating that both proteins are able to bind to the $\operatorname{modA} 2$ promoter (Figures $4 \mathrm{~B}$ and C). The presence of the DNA-protein complex in the well may suggest that a high molecular mass complex is formed, although, since the complex is disrupted by unlabelled homologous DNA, it is unlikely to be a result of protein-DNA precipitation. Molybdate did not interfere in the DNA-binding under our experimental conditions, since similar DNA binding was observed when we added $1 \mathrm{mM}$ sodium molybdate (data not shown). The lack of molybdate-dependent binding in our experiments may have been due to the presence of trace amounts of molybdenum in the chemicals and solutions used for protein purification, which could be sufficient to saturate His-ModE1. A similar effect was observed in the binding of purified $E$. coli ModE to the moaA promoter region (McNicholas et al., 1997). Since DNA-binding was observed in the presence of herring DNA and the dilution-out of the DNA-protein complex occurred using unlabelled competitor DNA, our results indicate that $H$. seropedicae His-ModE1 was oncolumn refolded to an active form that recognized and bound the $H$. seropedicae modA2 promoter region. The over-expressed and purified His-ModE2 protein also recognized and bound the same DNA fragment.

\section{Overview}

In this study the fusion proteins ModE1 and ModE2 were not only expressed and purified but also assayed for

A

$5, .$. Bam ${ }_{\text {gatcceccettgecggggecgaaggegatggtctcgecctgeatcacacge }}$

acgegtaaggtcttggaatcatt CAT GCGCGTGATTGTACAAGGGCGCCCCGGCAGCGGCCA

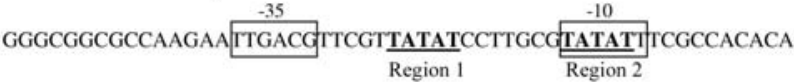

CCACCACACCACTACACGCCGCCACGCGCTGTTCGTGCTTGGCCTTTCCTGTCCA

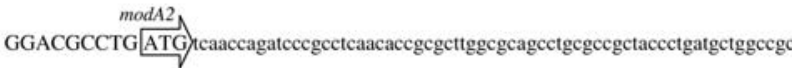
Nhel

Tggegecgeccaggccgecgatctggtggtcteggcagcgg ${ }^{\top}$ ctagc

B Consensus H. seropedicae

ATCGTTATATANAAGAATATATAACGAT TTCGTTATATCCTTGCGTATATITCGCC

$$
\text { Region } 1 \quad \text { Region } 2
$$

Figure 3 - Panel A shows the nucleotide sequence of the 340 bp DNA fragment containing the $H$. seropedicae $\bmod E 2-\bmod A 2$ intergenic region. Large arrows indicate the transcription direction of $\bmod E 1$ and $\bmod A 2$. The -10/-35 type promoter region of $\bmod A 2$ are shown in boxes and the predicted ModE-binding sites (regions 1 and 2) are in bold and underlined. Panel B shows the nucleotide alignment of a consensus sequence for ModE-binding. The base 5 of the consensus presented the same degree of conservation for nucleotides $\mathrm{A}$ and $\mathrm{T}$ among the sequences used for the alignment, with ' $\mathrm{N}$ ' indicating any nucleotide (Studholme and Pau, 2003; BMC Microbiol. 3, doi: 10.1186/1471-2180-3-24).

their in vitro DNA-binding activities. Both proteins were able to bind the $\bmod A 2$ promoter, suggesting involvement in the regulation of the transcription of $\bmod A 2 B 2 C 2$ genes in $H$. seropedicae. Additional studies involving the charac-

A His-ModE1 His-ModE2

$0 \longdiv { 1 0 0 2 0 0 4 0 0 8 0 0 } \overline { 1 0 0 2 0 0 4 0 0 8 0 0 }$
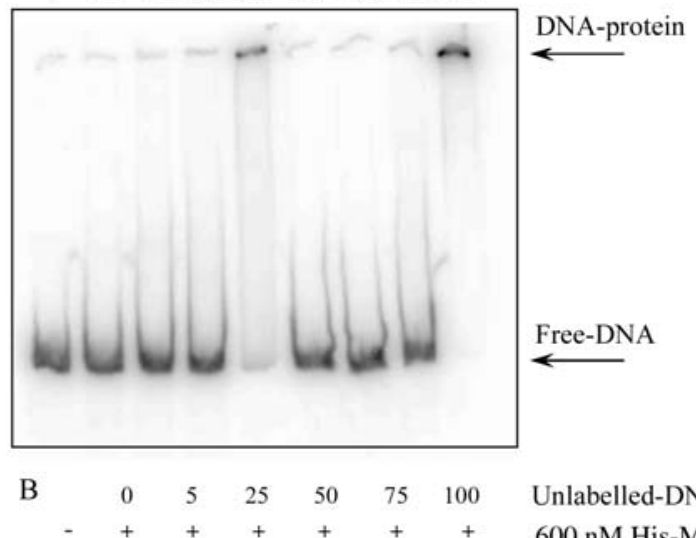

Unlabelled-DNA (nM)

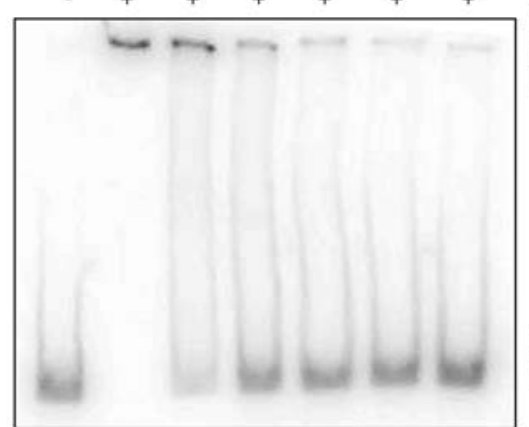

$600 \mathrm{nM}$ His-ModE1

DNA-protein

Free-DNA

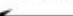

C

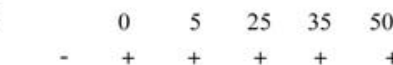

Unlabelled-DNA (nM)

$600 \mathrm{nM}$ His-ModE2

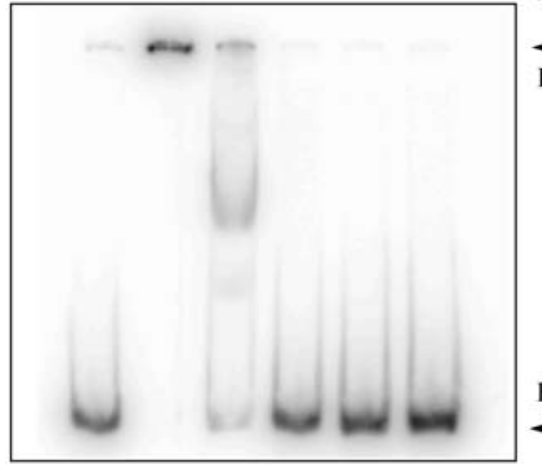

DNA-protein

Free-DNA

Figure 4 - DNA band-shift assay with the H. seropedicae His-ModE1 and His-ModE2 proteins and a $340 \mathrm{bp}$ DNA fragment containing the $\operatorname{modA} 2$ promoter region. Experiments were carried out as described in the Material and Methods. Panel A shows the amount (nM) of purified His-ModE1 and His-ModE2 incubated with $5 \mathrm{nM}$ of $\left[{ }^{32} \mathrm{P}\right]$-labeled $\bmod A 2$ promoter region in the presence of $3 \mu \mathrm{g} / \mathrm{mL}$ of herring DNA. Panel B shows the amount (nM) of unlabeled competitor DNA added to a reaction mixture containing $600 \mathrm{nM}$ of purified His-ModE1 and $5 \mathrm{nM}$ of $\left[{ }^{32} \mathrm{P}\right]$-labeled $\bmod A 2$ promoter region. Lane (-) shows sample containing only the $\left[{ }^{32} \mathrm{P}\right]$-labeled DNA. Panel $\mathrm{C}$ shows the amount $(\mathrm{nM})$ of unlabeled competitor DNA incubated with $600 \mathrm{nM}$ of purified His-ModE2 and $5 \mathrm{nM}$ of $\left[{ }^{32} \mathrm{P}\right]$-labeled promoter region of $\bmod A 2$. Lane (-) shows sample containing only the $\left[{ }^{32} \mathrm{P}\right]$-labeled DNA. Arrows indicate the migration of freeDNA or DNA bound to protein. Autoradiograms were obtained using Storm 820 Phosphorimager. 
terization of $\operatorname{modE} 1$ and $\bmod E 2$ mutants aimed at elucidating their physiological roles in the regulation of molybdate uptake will contribute to a better understanding of this process in H. seropedicae.

\section{Acknowledgments}

We are grateful to the H. seropedicae Genome Sequencing Consortium (GENOPAR) for the clone used in the work, computational annotation and additional support. We are also grateful to Valter de Baura, Roseli Prado and Julieta Pie for technical assistance, and to Dr. M.G. Yates for the criticism in reading the manuscript and suggestions. This work was supported by the Brazilian agencies $\mathrm{CNPq} / \mathrm{MCT}$, CAPES, CNPq, Paraná Tecnologia and Fundação Araucária.

\section{References}

Anderson LA, Palmer T, Price NC, Bornemann S, Boxer DH and Pau RN (1997) Characterisation of the molybdenum-responsive ModE regulatory protein and its binding to the promoter region of $\bmod A B C D$ (molybdenum transport) operon of Escherichia coli. Eur J Biochem 246:119-126.

Anderson LA, McNairn E, Leubke T, Pau RN and Boxer DH (2000) ModE-dependent molybdate regulation of the molybdenum cofactor operon moa in Escherichia coli. J Bacteriol 182:7035-7043.

Baldani JI, Baldani VLD, Seldin L and Döbereiner J (1986) Characterization of Herbaspirillum seropedicae gen. nov., sp. nov., a root-associated nitrogen-fixing bacterium. Intl J Sys Bact 36:86-93.

Bradford MM (1976) A rapid and sensitive method for the quantification of microgram quantities of protein utilizing the principle of protein dye binding. Anal Biochem 72:248-254.

Corcuera GL, Bastidas M and Dubourdieu M (1993) Molybdenum uptake in Escherichia coli K12. J Gen Microbiol 139:1869-1875.

Gourley DG, Schüttelkopf AW, Anderson LA, Price NC, Boxer DH and Hunter WN (2001) Oxyanion binding alters conformational and quaternary structure of the $\mathrm{C}$-terminal domain of the transcriptional regulator ModE. J Biol Chem 276:20641-20647.

Grunden AM, Ray RM, Rosentel JK, Healy FG and Shanmugam KT (1996) Repression of the Escherichia coli modABCD (molybdate transport) operon by ModE. J Bacteriol 178:735-744.

Grunden, AM and Shanmugam KT (1997) Molybdate transport and regulation in bacteria. Arch Microbiol 168:345-354.

Grunden AM, Self WT, Villain M, Blalock JE and Shanmugam KT (1999) An analysis of the binding of repressor protein ModE to $\operatorname{modABCD}$ (Molibdate transport) operator/promoter DNA of Escherichia coli. J Biol Chem 274:2430824315.

Hall DR, Gourley DG, Leonard GA, Duke EMH, Anderson LA, Boxer DH and Hunter WN (1999) The high-resolution crystal structure of the molybdate-dependent transcriptional reg- ulator (ModE) from Escherichia coli: A novel combination of domain folds. EMBO J 18:1435-1446.

Hille R (1996) The mononuclear molybdenum enzymes. Chem Rev 96:2757-2816.

Klassen G, Pedrosa FO, Souza EM, Yates MG and Rigo,LU (1999) Sequencing and functional analysis of the nifENXorflorf2 gene cluster of Herbaspirillum seropedicae. FEMS Microbiol Lett 181:165-170.

Laemmli UK. (1970) Cleavage of structural proteins during the assembly of the head of bacteriophage T7. Nature 227:680685.

Letunic I, Copley RR, Pils B, Pinkert S, Schultz J and Bork P (2006) SMART 5: Domains in the context of genomes and networks. Nucleic Acids Res 34:D257-260.

Machado IMP, Yates MG, Machado HB, Souza EM and Pedrosa FO (1996) Cloning and sequencing of the nitrogenase structural genes nifHDK of Herbaspirillum seropedicae. Braz $\mathbf{J}$ Med Biol Res 29:1599-1602.

McNicholas PM, Chiang RC and Gunsalus RP (1998a) Anaerobic regulation of the Escherichia coli dms $A B C$ operon requires the molybdate-responsive regulator ModE. Mol Microbiol 27:197-208.

McNicholas PM, Mazzotta MM, Rech SA and Gunsalus RP (1998b) Functional dissection of the molybdate-responsive transcription regulator, ModE, from Escherichia coli. J Bacteriol 180:4638-4643.

McNicholas PM, Rech SA and Gunsalus RP (1997) Characterization of the ModE DNA-binding sites in the control regions of modABCD and moaABCDE of Escherichia coli. Mol Microbiol 23:515-524.

Sambrook J, Fritsch EF and Maniatis T (1989) Molecular Cloning: A Laboratory Manual. 2nd ed. Cold Spring Harbor Laboratory Press, New York.

Schneider KA, Muller A, Schramm U and Klipp W (1991) Demonstration of a molybdenum- and vanadium- independent nitrogenase in a nifHDK deletion mutant of Rhodobacter capsulatus. Eur J Biochem 195:653-661.

Schultz J, Milpetz F, Bork P and Ponting CP (1998) SMART, a simple modular architecture research tool: Identification of signaling domains. Proc Natl Acad Sci USA 95:5857-5864.

Schüttelkopf AW, Boxer DH and Hunter WN (2003) Crystal structure of activated ModE reveals conformational changes involving both oxyanion and DNA-binding domains. J Mol Biol 326:761-767.

Self WT, Grunden AM, Hasone A and Shanmugam KT (2001) Molybdate transport. Res Microbiol 152:311-321.

Souza EM, Pedrosa FP, Rigo LU, Machado HB and Yates MG (2000) Expression of the nifA gene of Herbaspirillum seropedicae: Role of the NtrC and NifA binding sites and of the -24/-12 promoter element. Microbiology 146:14071418.

Studholme DJ and Pau RN (2003) A DNA element recognized by the molybdenum-responsive transcription factor ModE is conserved in Proteobacteria, green sulphur bacteria and Archaea. BMC Microbiol 3, doi: 10.1186/1471-2180-3-24.

Tao H, Hasona A, Do PM, Ingram LO and Shanmugam KT (2005) Global gene expression analysis revealed na unsus- 
pected deo operon under the control of molybdate sensor ModE protein, in Escherichia coli. Arch Microbiol 184:225-233.

Young JPW (1992) Phylogenetic classification of nitrogen-fixing organisms. In: Stacey G, Burris RH and Evans HJ (eds), Biological Nitrogen Fixation. Chapman \& Hall, New York, pp 43-88.

Wang G, Angermüller S and Klipp W (1993) Characterization of Rhodobacter capsulatus genes encoding a molybdenum transport system and putative molybdenum-pterin-binding proteins. J Bacteriol175:3031-3042.

Wiethaus J, Wirsing A, Narberhaus F and Masepohl B (2006) Overlapping and specialized functions of the molybdenum- dependent regulators MopA and MopB in Rhodobacter capsulatus. J Bacteriol 188:8441-8451.

\section{Internet Resources}

H. seropedicae Genome Sequencing Project, http://www. genopar.org/.

Simple Modular Architecture Research Tool (SMART), http:// smart.embl-heidelberg.de/

Protein Family (Pfam), http://www.sanger.ac.uk/. Associate Editor: Luis Carlos de Souza Ferreira

License information: This is an open-access article distributed under the terms of the Creative Commons Attribution License, which permits unrestricted use, distribution, and reproduction in any medium, provided the original work is properly cited. 